Creative Commons User Licence: CC BY-NC-ND

Abstracted by: EBSCOhost, Electronic Journals Service (EJS),

Google Scholar, Directory of Open Access Journals (DOAJ),

Journal Seek, Scientific Commons, and

Food and Agricultural Organization (FAO)
Journal of Agricultural Extension

Vol.19 (1) June, 2015

ISSN 24086851

http://journal.aesonnigeria.org

http://www.ajol.info/index.php/jae

\title{
http://dx.doi.org/10.4314.jae.v19i1.10
}

\section{Determinants of Adoption of Cassava Technologies by Male Farmers in Nasarawa State, Nigeria}

\section{Mercy Ebele Ejechi}

National Root Crops Research Institute, Umudike

\section{Abstract}

The study investigated determinants of adoption of recommended cassava production technologies among male farmers in Nasarawa State. Multi-stage sampling technique was employed for the selection of the respondent. Structured questionnaire was used for data collection. The data were collected from 60 male cassava farmers selected from 6 out of 13 LGAs in the State. They were Karu, Kokona, Akwanga, NasarawaEggon, Lafia and Obi. Data were analysed with both descriptive and inferential statistics. Descriptive statistics such as frequency tables, and percentage were used to describe socio-economic characteristics of the respondents. Logit regression model was used to estimate the determinants of adoption of these practices. The results showed that awareness and adoption of these practices were very high (Awareness of all the practices ranges from $90 \%$ to 98.3\% while the adoption is from $63.3 \%$ to 90\%). Factors that positively and significantly influenced adoption by male farmers were income $(p=0.01)$ and extension contact $(p=0.1)$. The conclusion was that men made remarkable contribution in cassava production. It was recommended that Governments at all levels formulate policies aimed at encouraging and motivating male cassava farmers. Provision of loans to male farmers and subsidizing of inputs should be ae necessary. Cassava processing industries should be established to add value and increase income.

Keywords: Adoption, Cassava Technologies, Male farmers. 
Creative Commons User Licence: CC BY-NC-ND

Abstracted by: EBSCOhost, Electronic Journals Service (EJS),

Google Scholar, Directory of Open Access Journals (DOAJ),

Journal Seek, Scientific Commons, and

Food and Agricultural Organization (FAO)
Journal of Agricultural Extension

Vol.19 (1) June, 2015

ISSN 24086851

http://journal.aesonnigeria.org

http://www.ajol.info/index.php/jae

\section{Introduction}

Cassava plays a key role in Africa development as famine reserve crop, rural food staple, cash crop for urban consumption, and raw materials for livestock and industry (Nweke et al,. 2002).Cassava does well on poor and marginal soils in comparison with other crops (Alabi and Alabi, 2002). It has become the most important root crop in tropical Africa providing food for over 200 million people (IITA, 1992). Almost all the cassava produced in Nigeria is used for human consumption and less than 5\% goes for industrial raw materials (Ajayi and Onuche, 2005). Cassava is of great economic importance in Nigeria as it serves as a major staple food. Cassava is processed into various forms such as gari, fufu, cassava flour and starch (Odurukwe et al., 2003,). Apart from its use as food, cassava is an important industrial raw material for the production of alcohol, pharmaceutical gum and confectionaries (Okonkwo, 2002). As a result, demand presently outstrips production.

Furthermore, Cassava for a long time has been a versatile staple food crop for the people of Nasarawa state. It is well adapted to the traditional farming systems of the area. Small-scale farmers, majority of who are rural youths, play a major role in cassava production in study Area. A number of recommended practices such as timely planting, fertilizer application, timely weeding, herbicide application, insecticide application and planting of stems inclined on ridges which will produce tuberous roots in the same direction to make harvesting easier, have been introduced in an attempt to increase yield per hectare of cassava production Institute for Agricultural Research and Training (IAR\&T, 2005).

The improvement in the yield of cassava is vigorously pursued through the development of improved varieties by National Root Crops Research Institute, Umudike and International Institute for Tropical Agriculture (IITA), Ibadan, as well as through Agricultural Extension (Agbarevo and Obinne 2008).

Adoption of improved production practices by farmers leads to improved yields of crops. Studies have shown positive correlation between adoption of extension recommendations by farmers and crop yields which translate into increased income and improved quality of life of farmers (African rice centre, 2007). Similarly, Emenyonu et al. (2005) reported significant difference between 
Creative Commons User Licence: CC BY-NC-ND

Abstracted by: EBSCOhost, Electronic Journals Service (EJS),

Google Scholar, Directory of Open Access Journals (DOAJ),

Journal Seek, Scientific Commons, and

Food and Agricultural Organization (FAO)
Journal of Agricultural Extension

Vol.19 (1) June, 2015

ISSN 24086851

http://journal.aesonnigeria.org

http://www.ajol.info/index.php/jae

cassava yield of farmers adopting improved cassava production technologies and those not adopting the recommendations in Delta state. However, for a successful adoption of a technology, farmers must not only know about it, but must be able to follow the recommendation given (Adekoya and Tologbonse 2005). A thorough knowledge of the target group in the development and dissemination of the technology is a prerequisite to adoption of the technology in question.

Male farmers play a central role in cassava production, processing and marketing. They are responsible for cassava production which provides additional income earning opportunities, and enhances their ability to contribute to household food security (Ojuekaiye, 2001).

However, in the face of the present food insecurity facing the country, the need to sustain cassava production is unarguable. Cassava has vast food derivatives and many uses; some of its food values include: tapioca, fufu, tuwo and High Quality Cassava flour. The yield of the crop is influenced by the quality of planting material and management practices. Okeke and Eke-okoro (2006) reported high cassava yield from use of improved Nigerian cultivars. But better yields are obtained when improved cassava genotypes are used with suitable cultural practices (Udealor and Asiegbu, 2006).

Cassava was traditionally grown by males in Nasarawa state but recent time there is increasing involvement of females in its production. With the low productivity of cassava farmers and efforts of Nigerian government to increase its production through extension services of the ADPs and technology adoption among farmers, more information on gender adoption of improved cassava production technology is desirable. Therefore, there is need to ascertain the adoption behaviour by male farmers of the various components of the cassava production technology among farmers in the study area.

Specifically, the study was designed to:

1. describe the socio economics characteristics of the respondents in the study area.

2. ascertain the level of awareness and adoption of cassava technologies.

3. identify the determinant of adoption of cassava technologies. 
Creative Commons User Licence: CC BY-NC-ND

Abstracted by: EBSCOhost, Electronic Journals Service (EJS),

Google Scholar, Directory of Open Access Journals (DOAJ),

Journal Seek, Scientific Commons, and

Food and Agricultural Organization (FAO)
Journal of Agricultural Extension

Vol.19 (1) June, 2015

ISSN 24086851

http://journal.aesonnigeria.org

http://www.ajol.info/index.php/iae

\section{Methodology}

This study was conducted in Nasarawa State in 2012. Purposive sampling technique was employed. Six out of thirteen LGAs in Nasarawa State were selected for the study. They were Karu, Kokona, Akwanga, Nasarawa eggon, Lafia and Obi. Two villages were selected from each of the LGAs and five male cassava farmers were selected in each of these villages making a total of 60 farmers. Focus Group Discussion and interview schedule with well structured questionnaire were used to elicit information from the respondents. Data were collected on socio-economic characteristics of respondents and improved agronomic practices involved in the production of cassava which include (1) use of improved varieties of cassava, (2) use of herbicide (such as Atrazine and Paraquat), (3) use of fertilizer (NPK), (4) appropriate plant spacing at $1 \mathrm{~m} \times 1 \mathrm{~m},(5)$ planting time (June-July), (6) use of tractor for tillage, (7) use of insecticides, (8) harvesting time (9-12 months).

Frequencies, percentage, were used for objective one and two and logit regression model was use to achieve objective 3 .

The logit model was expressed implicitly as

$\mathrm{Y}=\mathrm{F}\left(\mathrm{X}_{1}, \mathrm{X}_{2}, \mathrm{X}_{3}, \mathrm{X}_{4}, \mathrm{X}_{5}, \mathrm{X}_{6}, \mathrm{X}_{7}, \mathrm{X}_{8}, \mathrm{X}_{9}, \mathrm{X}_{10}, \mathrm{X}_{11}, \mathrm{X}_{12}, \mathrm{X}_{13}, \mathrm{X}_{14}\right)$

Explicitly the model is specified as

$\mathrm{Y}($ Adoption $)=\mathrm{b} 0+\mathrm{b}_{1} \mathrm{X}_{1}+\mathrm{b}_{2} \mathrm{X}_{2}+\mathrm{b}_{3} \mathrm{X}_{3}+\mathrm{b}_{4} \mathrm{X}_{4}+\mathrm{b}_{5} \mathrm{X}_{5}+\mathrm{b}_{6} \mathrm{X}_{6}+\mathrm{b}_{7} \mathrm{X}_{7}+\mathrm{b}_{8} \mathrm{X}_{8}+\mathrm{b}_{9} \mathrm{X}_{9}+\mathrm{b}_{10} \mathrm{X}_{10}+\mathrm{b}_{11} \mathrm{X}_{11}+\mathrm{b}_{12} \mathrm{X}_{12}+$

$\mathrm{b}_{13} \mathrm{X}_{13}+\mathrm{b}_{14} \mathrm{X}_{14}+\mathrm{U}$

Where,

$\mathrm{Y}($ Adoption $)=(1$ for adoption, 0 otherwise $)$

$\mathrm{X}_{1}$ : Age of farmers (in years)

$\mathrm{X}_{2}:$ Sex $($ male $=1$, Female $=0)$

$\mathrm{X}_{3}$ : Marital Status (Married=1, Not married=0) 
Creative Commons User Licence: CC BY-NC-ND

Abstracted by: EBSCOhost, Electronic Journals Service (EJS),

Google Scholar, Directory of Open Access Journals (DOAJ),

Journal Seek, Scientific Commons, and

Food and Agricultural Organization (FAO)
Journal of Agricultural Extension

Vol.19 (1) June, 2015

ISSN 24086851

http://journal.aesonnigeria.org

http://www.ajol.info/index.php/iae

$\mathrm{X}_{4}$ : Household size (Number of people feeding from the same pot)

$\mathrm{X}_{5}$ : Educational status (years of formal schooling)

$\mathrm{X}_{6}$ : level of annual income (naira)

$\mathrm{X}_{7}$ : Farming experience (years)

$\mathrm{X}_{8}$ : Membership of cooperative associations (membership=1, Non=0)

$\mathrm{X}_{9}$ : Total farm size ( hectares)

$\mathrm{X}_{10}$ : Contact with extension staff (months)

$\mathrm{X}_{11}$ : Complexity of the technology $($ complex $=1$, non complex $=0)$

$\mathrm{X}_{12}$ : Profitability $($ profitable $=1$, non profitable $=0$ )

$\mathrm{X}_{13}$ : Adaptability (Adaptable 1, non adaptable $=0$ )

$\mathrm{X}_{14}$ : Compatibility (Compatible1, incompatible $=0$ )

Where:

$\mathrm{Y} \& \mathrm{X}_{1}-\mathrm{X}_{14}$ as defined above.

$\mathrm{b}_{0}=$ constant

$\mathrm{b}_{1}-\mathrm{b}_{14}=$ coefficient to be estimated.

U: Error term.

\section{Results and Discussion}

\section{Socio-economic characteristics of respondents}

The result in Table1 show that the majority (63.3\%) of male farmers were within 41-60 years of age. The mean age of farmers was 46.7. This result implied that farmers were still at their productive age (41-60) and dominated cassava production in the study area. However, according to Nwaru (2004), the ability of a farmer to reduce risk, be innovative decreases with age, there was 
Creative Commons User Licence: CC BY-NC-ND

Abstracted by: EBSCOhost, Electronic Journals Service (EJS),

Google Scholar, Directory of Open Access Journals (DOAJ),

Journal Seek, Scientific Commons, and

Food and Agricultural Organization (FAO)
Journal of Agricultural Extension

Vol.19 (1) June, 2015

ISSN 24086851

http://journal.aesonnigeria.org

http://www.ajol.info/index.php/iae

likely to be a high prospect for increased adoption of improved cassava production technologies among the middle aged farmers. Majority (95\%) of the farmers were married. Marriage in African culture connotes respect and responsibility to demand in terms of income to meet family needs as well as increase in family labour. Enitan (2010) in similar studies found out that majority of married people are into agricultural production. For educational level, 38.3\% of male farmers had one form of tertiary education or the other, $18.3 \%$ had secondary education, $20 \%$ had primary education, $15 \%$ had quaranic education, while $8.3 \%$ had no education. The farmers in the study area having more tertiary education were expected to have access to information, be more receptive to improved farming technique and have more ability and willingness to adopt technologies. The result on land area cultivated by farmers revealed that majority (55\%) of the farmers cultivated land between $1-4$ ha, $41.7 \%$ cultivated 5 ha and above while only $1.7 \%$ cultivated below 1 ha. The mean for land area was 3.6. The size of land available to the farmer is likely to have positive influence on adoption (Ironkwe, 2005) this is because the farmers with larger size of farm could afford to invest relatively small portion to venture into an uncertain enterprises and hence adoption becomes possible. For farming experience, the result showed that (35\%) of farmers had less than 11years cassava farming experience, $28.4 \%$ had between 11-20 years experience, $25 \%$ had between 21-30years and $11.7 \%$ of the male farmers had above 30 years Cassava farming experience. The mean for farming experience was 18. This result implies that experienced farmers are in cassava production in the study area with more experience in farming, the farmers could be less averse to the risk involved in adopting new innovation. Hence, there would be an increase adoption of technology among male farmers; this is because the farmer's previous experience with other innovations either positive or negative would influence his perception of the importance of the technology (ghandin and panel, 1999). 
Table1: Distribution of respondents on socio-economic variables.

\begin{tabular}{lll}
\hline Socio-economic Variables & Percentage $(\mathrm{n}=60)$ & Mean \\
\hline Age & 3.3 & 46.7 \\
$<20$ & 20.0 & \\
$21-40$ & 63.6 & \\
$41-60$ & 13.3 & \\
$>60$ & & \\
Marital Status & 5.0 & \\
Single & 95.0 & \\
Married & & \\
Level of Education & 8.3 & \\
No formal Education & 15.0 & \\
Quaranic Education & 20.0 & \\
Primary Education & 18.3 & \\
Secondary Education & 38.3 & \\
Tertiary Education & & \\
Farm size & 1.7 & \\
$>1$ ha & 20.0 & \\
1-2ha & 34.0 & \\
3-4ha & 43.4 & \\
5ha and above & 35 & \\
Farming Experience & 28.4 & \\
$<11$ years & 25 & \\
11-20 & 11.7 & \\
21-30 & & \\
$>30$ & &
\end{tabular}

Source: Field Survey, 2012

\section{Adoption level of cassava production technologies}

Table 2 shows the level of adoption of recommended production technologies, higher adopters constituted (63.3\%) while lower adopters constituted (36.3\%). For the eight technologies studied, any respondent that adopts six technologies and above is regarded as higher adopter while any respondent that adopts less than six technologies is regarded as lower adopter. 
Creative Commons User Licence: CC BY-NC-ND

Abstracted by: EBSCOhost, Electronic Journals Service (EJS),

Google Scholar, Directory of Open Access Journals (DOAJ),

Journal Seek, Scientific Commons, and

Food and Agricultural Organization (FAO)
Journal of Agricultural Extension

Vol.19 (1) June, 2015

ISSN 24086851

http://journal.aesonnigeria.org

http://www.ajol.info/index.php/jae

Table 2: Distribution of respondents by level of adoption of cassava production technologies

$\begin{array}{lll}\text { Adoption level } & \text { Percentage } & \text { Mean Score }\end{array}$

High adopters

63.3

6

Low adopters

36.3

Total

100

Source: Field Survey, 2012.

\section{Awareness and adoption of cassava production technologies}

Table 3 explains that all the farmers in the study area were aware of the eight cassava production practices studied. These includes use of improved cassava varieties (90\%), use of fertilizer (76.7\%), herbicide(63.3\%), and insecticide (63.3), appropriate plant spacing (1mx $1 \mathrm{~m})(66.7 \%)$, planting time (June/July) (85\%), use of tractor (43.3\%) and harvesting time (78.3\%). The adoption level for use of tractor by the male cassava farmers was low (43.3\%). This may be attributed to high cost of procuring tractor or unavailability of it.

Table 3: Distribution of respondents on awareness and adoption of cassava production technologies.

\begin{tabular}{lll}
\hline Production technologies & $\begin{array}{l}\text { Aware }(n=60) \\
\text { percentage }\end{array}$ & $\begin{array}{l}\text { Adopted }(n=60) \\
\text { Percentage }\end{array}$ \\
\hline Improved cassava & 98.3 & 90 \\
Use of herbicide & 98.3 & 86.7 \\
Use of fertilizer & 93.3 & 76.7 \\
Use of insecticide & 91.7 & 63.3 \\
Appropriate plant spacing & 90 & 66.7 \\
Planting time & 95 & 85 \\
Use of tractor & 90 & 43.3 \\
Harvesting time & 93.3 & 78.3 \\
\hline
\end{tabular}

Source: Field Survey, 2012 
Creative Commons User Licence: CC BY-NC-ND

Abstracted by: EBSCOhost, Electronic Journals Service (EJS),

Google Scholar, Directory of Open Access Journals (DOAJ),

Journal Seek, Scientific Commons, and

Food and Agricultural Organization (FAO)
Journal of Agricultural Extension

Vol.19 (1) June, 2015

ISSN 24086851

http://journal.aesonnigeria.org

http://www.ajol.info/index.php/jae

\section{Determinant of adoption of cassava production technologies}

The result of the logit regression analysis (Table 4) revealed that income and number of extension contact are positive and significant to adoption of cassava technologies at varying degree of significance. This implies that income of the farmer significantly influenced the adoption of cassava technologies. As income increases, adoption also increases. Number of extension contact also increases adoption rate. According to Okonkwo et al. (2009). Adoption of improved technologies increases with increase in the number of extension contacts. This is because the farmers are likely to receive more valuable information about technologies from the extension agents during such visit.

Table 4: Logit estimates of determinant of adoption of cassava production technologies

\begin{tabular}{llll}
\hline Variable & Coefficient & Standard Error & Z value \\
\hline Age & .0205 & .0328126 & 0.63 \\
Household size & -.0788 & .1441918 & -0.55 \\
Education & .0396 & .0429924 & 0.92 \\
Income & $3.19 \mathrm{e}-{ }^{*}$ & $1.79 \mathrm{e}-06$ & 1.78 \\
Experience & -.0263 & .0546349 & -0.48 \\
Cooperative & .7376 & .8812638 & 0.84 \\
Farm size & .3643 & .5006137 & 0.73 \\
Extension contact & $.7306 * * *$ & .2062525 & 3.54 \\
Technically Complexity & -.3193 & .8942661 & -0.36 \\
Constant & -5.0779 & 3.010661 & -1.69 \\
$\mathrm{X}^{2} 0.000$ & & & \\
Total Sample & 60 & & \\
\hline$* * * \mathrm{P}<0.01, * \mathrm{P}<0.10$ & & & \\
\hline
\end{tabular}

Source: Data analysis, 2012. 
Creative Commons User Licence: CC BY-NC-ND

Abstracted by: EBSCOhost, Electronic Journals Service (EJS),

Google Scholar, Directory of Open Access Journals (DOAJ),

Journal Seek, Scientific Commons, and

Food and Agricultural Organization (FAO)
Journal of Agricultural Extension

Vol.19 (1) June, 2015

ISSN 24086851

http://journal.aesonnigeria.org

http://www.ajol.info/index.php/jae

\section{Conclusion and Recommendation}

It can be concluded that awareness and adoption level of cassava technologies were quite high in the study area. (Awareness of all the practices ranges from $90 \%$ to $98.3 \%$ while the adoption is from $63.3 \%$ to $90 \%$ ). Also, that man made remarkable contribution in cassava production. It was therefore recommended that Farmers should adhere strictly to recommended packages by extension agents for increased output. Also, agricultural inputs should be made available to farmers at subsidized rates and timely too. This will improve cassava production in the study area.

Processing centers should also be established to enhance value addition to cassava which will increase income of cassava farmers in the study area.

\section{References}

Adekoya, A.E. and Tologbonse, E.B. (2005). Adoption and diffusion of innovations. In S.F. Adedoyin (ed) Agricultural Extension in Nigeria. Agricultural society of Nigeria (AESON)pp 28.

Africa Rice Centre (2007). Commodity watch: NERICA contributes to record rice harvest in Africa. New Agricultural Digest Abuja: FIF (4):16.

Agbarevo and Obinne (2008). Evaluation of the effect of agricultural extension delivery in cassava production in Nigeria. A case study of Cross river State of Nigeria. Nigerian Agricultural journal 39 (1) pp 16-17.

Ajayi, R and Onuche, L. B. (2005). Extension implication of change in production cost in consumption pattern of cassava and its production under democratic economy in Dekina Local Government Area of Kogi State In Journal of Agricultural Extension. Agricultural Extension Society of Nigeria (AESON). Vol. 8:41-49.

Alabi, O. O. and Alabi, O. A. (2002). Economics of cassava production in Kogi State. A case study of Yagba West Local Government Area. Savannah Journal of Science and Agriculture: 1(1): 105-109.

Emenyonu, C.A, M.A Odii, and S.U.Onyeagbocha, (2005). Comparative analysis of resource use productivity among Green River and non -Green River project farmers in the Niger Delta. Journal of Agricultural Research. 2 (2) : pp 57-63.

Ghadim, A.K. and D.J. Pannell (1999). Conceptual Framework of adoption of Agricultural Innovation. Journal of Agricultural Economics vol. 21: 145-154.

Institute for Agricultural Research and Training, (IAR\&T) (2005). Farmers' Guide on Cassava Production. Moore Plantation, Ibadan, Nigerians: 1-12

International Institute of Tropical Agriculture (1992). Sustainable Food Production in SubSaharan Africa, IITA's Contributions, Ibadan, Nigeria.

International Institute of Tropical Agriculture (2004): Annual report 1984. Ibadan, Nigeria.

Ironkwe,A.G. (2005). Adoption of yam minisett technology by women farmers in Abia State, Nigeria. An unpublished Msc. Thesis in the Department of Rural Sociology and extension, Michael Okpara University of Agriculture umudike. 
Creative Commons User Licence: CC BY-NC-ND

Abstracted by: EBSCOhost, Electronic Journals Service (EJS),

Google Scholar, Directory of Open Access Journals (DOAJ),

Journal Seek, Scientific Commons, and

Food and Agricultural Organization (FAO)
Journal of Agricultural Extension

Vol.19 (1) June, 2015

ISSN 24086851

http://journal.aesonnigeria.org

http://www.ajol.info/index.php/iae

Nwaru, J.C. (2004). Rural credit markets and arable crop production Imo State of Nigeria. Ph.D. Dissertation Michael Okpara University of Agriculture, Umudike Umuahia Nigeria.

Nweke, F.I., Spencer, O.S.C. and Lynam, J.K. (2002). The Cassava Transformation: Africa BestKept Secret. Michigan State University Press, East Lansing: 105.

Odurukwe, S. N., E.C. Njoku and A.I. Ugochukwu (2003). Determination of adoption gaps in yam minisett technique of women farmers in Rivers State, proceedings of $37^{\text {th }}$ Annual Conference of the Agricultural Society of Nigeria pp. 36-42.

Ojuekaiye, E. O. (2001). Economic analysis of cassava production in three local government areas of KogiState. M.Sc Thesis, Department of Agricultural economics and Rural Sociology, ABU, Zaria.

Okeke, J.E., \& Eke-okoro, O.N. (2006). Efficiency and productivity of Nigerian cassava cultivars. The Nigerian Agricultural journal 37, 53-59.

Okonkwo, M.O.,Okelola. O.E. and Nwangwu, A. (2009). Estimation of socio-economic factors of cassava rural farmers in Ikwo L.G.A of Ebonyi State. Global food crisis and Nigerian Agriculture. Proceedings of the $43^{\text {rd }}$ Annual conference of the Agricultural Society of Nigeria held at National Universities Commissions and Raw Materials Research and development Council, FCT, Abuja. 20-23 October pp 384-386.

Udealor, A., and Asiegbu, J.E. (2006). Effects of cassava genotype and vegetable cowpea populations on the component crop yield and system productivity in cassava/vegetable cowpea intercropping systems. The Nigerian agricultural journal 37: 74-80. 